\title{
Article \\ CLCA1 Regulates Airway Mucus Production and Ion Secretion Through TMEM16A
}

\author{
Raquel Centeio ${ }^{\dagger}$, Jiraporn Ousingsawat ${ }^{\dagger}$, Rainer Schreiber $(\mathbb{D}$ and Karl Kunzelmann $*$ (D) \\ Physiological Institute, University of Regensburg, University Street 31, D-93053 Regensburg, Germany; \\ raquel.martins-centeio@vkl.uni-regensburg.de (R.C.); jiraporn.ousingsawat@vkl.uni-regensburg.de (J.O.); \\ rainer.schreiber@vkl.uni-regensburg.de (R.S.) \\ * Correspondence: karl.kunzelmann@ur.de \\ † Equal contribution.
}

Citation: Centeio, R.; Ousingsawat, J.; Schreiber, R.; Kunzelmann, K. CLCA1 Regulates Airway Mucus Production and Ion Secretion Through TMEM16A. Int. J. Mol. Sci. 2021, 22, 5133. https://doi.org/ $10.3390 /$ ijms 22105133

Academic Editors: Anna Boccaccio and Simone Pifferi

Received: 11 April 2021

Accepted: 10 May 2021

Published: 12 May 2021

Publisher's Note: MDPI stays neutral with regard to jurisdictional claims in published maps and institutional affiliations.

Copyright: (c) 2021 by the authors. Licensee MDPI, Basel, Switzerland. This article is an open access article distributed under the terms and conditions of the Creative Commons Attribution (CC BY) license (https:// creativecommons.org/licenses/by/ $4.0 /)$.
Abstract: TMEM16A, a Ca ${ }^{2+}$-activated chloride channel (CaCC), and its regulator, CLCA1, are associated with inflammatory airway disease and goblet cell metaplasia. CLCA1 is a secreted protein with protease activity that was demonstrated to enhance membrane expression of TMEM16A. Expression of CLCA1 is particularly enhanced in goblet cell metaplasia and is associated with various lung diseases. However, mice lacking expression of CLCA1 showed the same degree of mucous cell metaplasia and airway hyperreactivity as asthmatic wild-type mice. To gain more insight into the role of CLCA1, we applied secreted N-CLCA1, produced in vitro, to mice in vivo using intratracheal instillation. We observed no obvious upregulation of TMEM16A membrane expression by CLCA1 and no differences in ATP-induced short circuit currents (Iscs). However, intraluminal mucus accumulation was observed by treatment with N-CLCA1 that was not seen in control animals. The effects of N-CLCA1 were augmented in ovalbumin-sensitized mice. Mucus production induced by N-CLCA1 in polarized BCi-NS1 human airway epithelial cells was dependent on TMEM16A expression. IL-13 upregulated expression of CLCA1 and enhanced mucus production, however, without enhancing purinergic activation of Isc. In contrast to polarized airway epithelial cells and mouse airways, which express very low levels of TMEM16A, nonpolarized airway cells express large amounts of TMEM16A protein and show strong CaCC. The present data show an only limited contribution of TMEM16A to airway ion secretion but suggest a significant role of both CLCA1 and TMEM16A for airway mucus secretion.

Keywords: CLCA1; TMEM16A; anoctamin 1; airway epithelium; mucus; MUC5AC; KCNN4

\section{Introduction}

TMEM16A is a $\mathrm{Ca}^{2+}$-activated chloride $\left(\mathrm{Cl}^{-}\right)$channel $(\mathrm{CaCC})$ that belongs to a family of 10 proteins, operating as phospholipid scramblases and $\mathrm{Cl}^{-}$channels [1]. In the lungs, TMEM16A is expressed at low levels in airway epithelial cells and airway and pulmonary arterial smooth muscle cells, and is upregulated during inflammatory airway diseases such as asthma and cystic fibrosis (CF) [2-5]. However, it remains unclear whether TMEM16A is particularly relevant for mucus production and mucus secretion or for secretion of electrolytes covering the airways (ASL) [5-7]. Earlier reports describe that TMEM16A is essential for the function of CFTR by providing local $\mathrm{Ca}^{2+}$ levels required for insertion of CFTR into the plasma membrane, and for full activation of CFTR through $\mathrm{Ca}^{2+}$-sensitive adenylate cyclase 1 [8-13].

Many studies associate expression of TMEM16A and the regulator of $\mathrm{Ca}^{2+}$-activated $\mathrm{Cl}^{-}$ channels, CLCA1, with goblet cell metaplasia and mucus production/secretion [3-5,14-17]. Inflammatory airway disease is associated with enhanced expression of CLCA1 in airway epithelial cells and high levels in the bronchoalveolar lavage (BAL) fluid [18,19]. It should be mentioned that, different than previously thought, CLCA1 is a secreted protein and a regulator of TMEM16A expression [20]. The so called von Willebrand factor type A (VWA) 
domain in secreted N-terminal CLCA1 was shown to serve as the minimal requirement for interaction and activation of TMEM16A [21,22]. Interestingly, the microtubular inhibitor nocodazole also augmented TMEM16A currents within minutes after exposure.

Expression of CLCA1 is enhanced in goblet cell metaplasia and associated with various lung diseases [17]. However, mice lacking expression of CLCA1 (mClca3 according to the earlier nomenclature) showed the same degree of mucous cell metaplasia and airway hyperreactivity as wild-type mice when challenged with viruses or allergens [23]. As CLCA1 is not essential for the development of mucous cell metaplasia, expression of other CLCA paralogs was proposed as a mechanism for functional redundancy. Using CLCA1-knockout mice, Mundhenk et al. found that CLCA1 does not contribute to basal, cAMP and $\mathrm{Ca}^{2+}$ regulated short circuit currents in mouse trachea. Notably, tracheal instillation of IL-13 in wt mice produced a strong upregulation of CLCA1, along with goblet cell metaplasia and mucin expression, but did not increase $\mathrm{Ca}^{2+}$-activated short circuit currents (Isc) [24]. In CLCA1-/ - tracheas, goblet cell metaplasia, mucin expression and $\mathrm{Ca}^{2+}$-activated Isc were similar, and no compensatory upregulation of CLCA5 was observed.

The controversies regarding the cellular function of CLCA1 triggered the present study, in which we examined the effects of secreted CLCA1 (N-CLCA1) in mouse airways in vivo and in airway epithelial cells in vitro. We found that CLCA1 augments intraluminal mucus, possibly by enhanced mucus production/secretion or by inducing mucus expansion. However, no clear increase in TMEM16A-dependent $\mathrm{Cl}^{-}$transport could be identified.

\section{Results}

\subsection{Asthmatic Conditions but Not CLCA1 Enhanced Expression of TMEM16A}

CLCA1 has been proposed to augment mucus production and to increase membrane expression of TMEM16A. However, available data are controversial and data from naïve airways are scarce. We therefore exposed mice in vivo to secreted $\mathrm{N}$-terminal CLCA1 protein, which was produced by expression of CLCA1 in HEK293 cells and harvesting of N-CLCA1 from the supernatant (Figure S1). N-CLCA1 or control buffer were applied to mouse airways by intratracheal instillation and animals were sacrificed $24 \mathrm{~h}$ later. Airway epithelial cells were harvested from isolated tracheas and expression of secretory ion channels and transporters such as Tmem16A, Cftr, Slc26a9, Kcnn4, as well as Muc5ac was analyzed. Except for Cftr, mRNA expression was not affected by N-CLCA1 (Figure 1A). Our data correspond to a previous report on excised human airway tissue stimulated with inflammatory cytokines in vitro [19]. Moreover, expression of TMEM16A was not detected in mock treated mouse trachea and only occasionally found in mucus producing epithelial cells by immunohistochemistry of N-CLCA1 tracheas (data not shown). Analysis of different airway sections demonstrated an impressive accumulation of mucus in the airways of N-CLCA1 treated animals, suggesting induction of mucus secretion by N-CLCA1 (Figure 1B). In contrast to N-CLCA1-induced secretion of mucus (lower panels), mucus was not detected in airways of mice treated with control supernatant (upper panels).

We also analyzed smaller airways from asthmatic mice sensitized in vivo towards ovalbumin. In contrast to treatment with N-CLCA1, transcriptional upregulation was observed of Tmem16a, Cftr and Muc5ac in airway epithelial cells of asthmatic airways, along with a small but significant increase in Kcnn4 expression (Figure 2A,B). Alcian blue staining indicated pronounced goblet cell metaplasia in airways of asthmatic mice [6] (Figure 2C, OVA, lower panel). Additional intratracheal application of N-CLCA1 in OVAsensitized asthmatic mice further augmented goblet cell metaplasia and induced mucus secretion with intraluminal accumulation in the airways. These effects of N-CLCA1 may be related to the mucus expanding properties of CLCA1 described earlier [25]. However, as previous studies demonstrated a role of TMEM16A for mucus secretion, N-CLCA1 may also induce mucus secretion through an increase in TMEM16A-function $[5,16,21]$. 

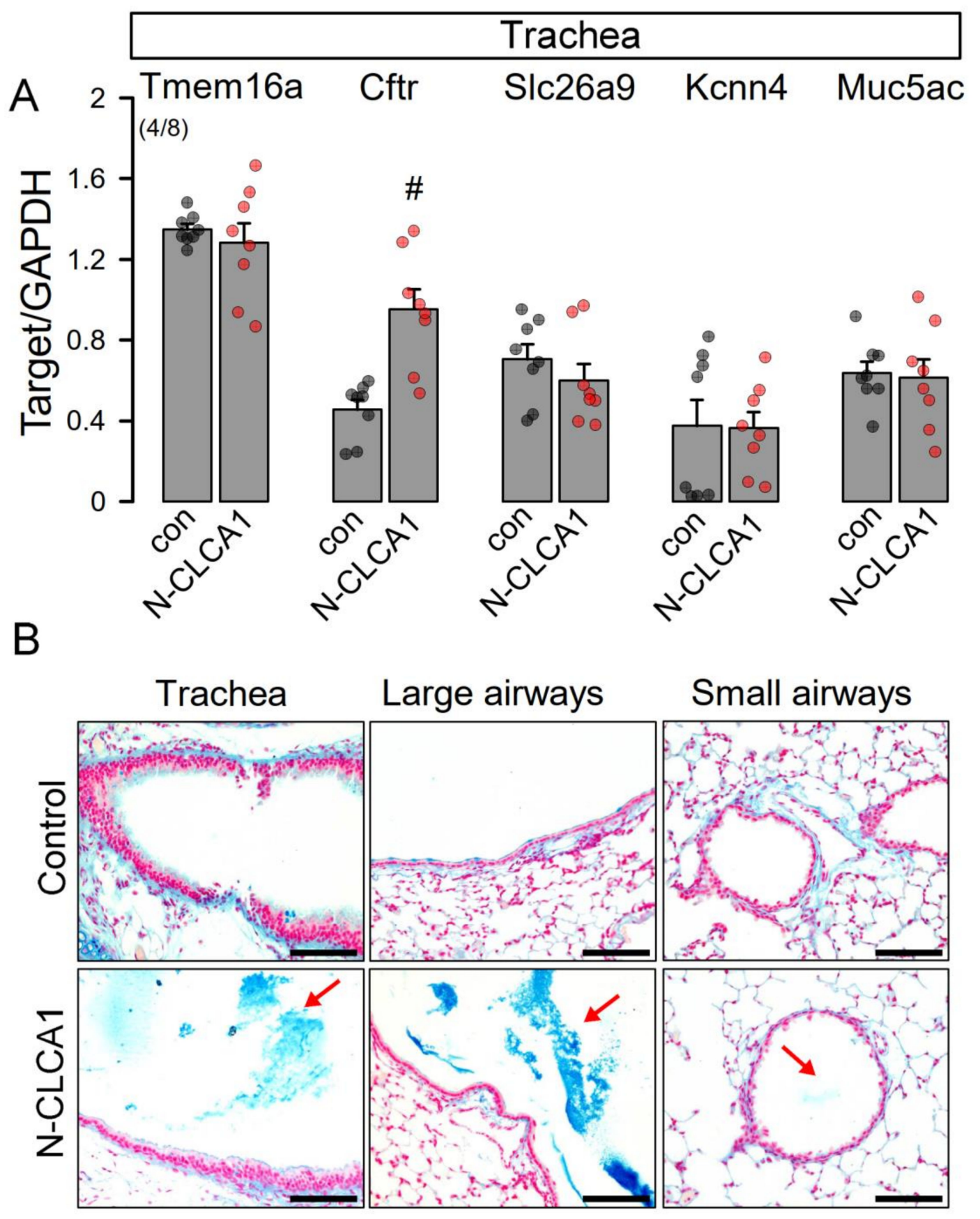

Figure 1. N-CLCA1 increases mucus production in vivo. (A) Semiquantitative RT-PCR analysis of the expression of MUC5AC, TMEM16A, CFTR, SLC26A9 and KCNN4 in isolated tracheal epithelial cells from control mice and mice treated for $24 \mathrm{~h}$ with N-CLCA1. Mean \pm SEM (number of animals/number of reactions). \#-significant difference when compared to control or mock ( $p<0.05$; unpaired $t$-test). (B) Alcian blue staining indicating enhanced mucus secretion in airways exposed to N-CLCA1. Bar $=100 \mu \mathrm{m}$. 

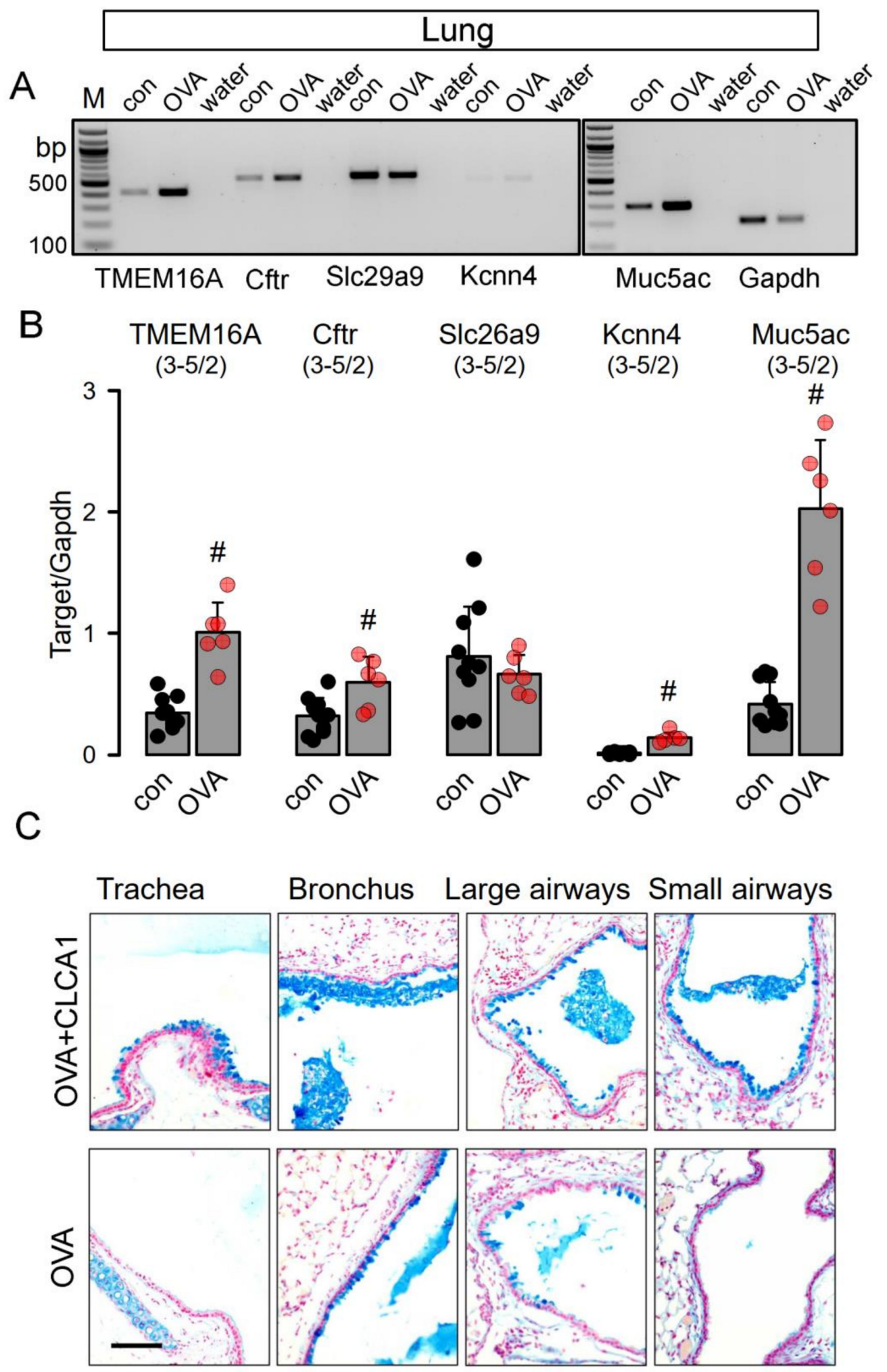

Figure 2. N-CLCA1 enhances mucus secretion in asthmatic mouse lungs in vivo. (A,B) Semiquantitative RT-PCR analysis of the expression of Tmem16a, Cftr, Slc26a9 and Kcnn4, and Muc5ac in lungs from control mice and OVA-treated mice. Expression of Tmem16a, Cftr, Kcnn4, and Muc5ac is enhanced in asthmatic (OVA) mice. Mean \pm SEM (number of animals/number of experiments). \#_significant difference when compared to control ( $p<0.05$; unpaired $t$-test). (C) Alcian blue staining of airways from OVA-sensitized mice treated with N-CLCA1 (upper panel) and OVA-sensitized mice without additional treatment with N-CLCA1 (lower panel). N-CLCA1 induced additional secretion of mucus with enhanced accumulation of the mucus in central and peripheral airways. Bar $=100 \mu \mathrm{m}$. 


\subsection{KCNN4 Is Upregulated in Asthma Which Counteracts Activation of TMEM16A}

Ion transport was assessed under open circuit conditions in tracheas of control mice and mice treated with N-CLCA1. No differences were found in basal amiloride-sensitive $\mathrm{Na}^{+}$absorption (Figure 3A,B). Moreover, ATP-activated ion transport was not different in N-CLCA1-treated mice when compared to control mice (Figure 3C,D). In the presence of the TMEM16A-blocker Ani9 or the KCNN4 inhibitor TRAM-34, both basal and ATPactivated transport were similar in CLCA1 and control treated airways (Figure 3E-H). Interestingly, we detected an upregulation of $\mathrm{KCNN} 4$ in tracheas and other airway sections of asthmatic (OVA-treated) mice (Figure 2A, Figure S2A-C). Moreover, KCNN4 was also upregulated by IL-13 in Calu3 airway epithelial cells (Figure S2D,E). We examined whether both $\mathrm{Ca}^{2+}$-activated $\mathrm{KCNN} 4 \mathrm{~K}^{+}$channels and TMEM16 $\mathrm{A} \mathrm{Cl}^{-}$channels are activated by increase in intracellular $\mathrm{Ca}^{2+}$ with ATP using patch clamp experiments, as this question cannot be clearly examined in Ussing chamber recordings. In fact, the data demonstrate, that KCNN4 is activated by increase in intracellular $\mathrm{Ca}^{2+}$, which corresponds to earlier observation by Lee and Fosket.

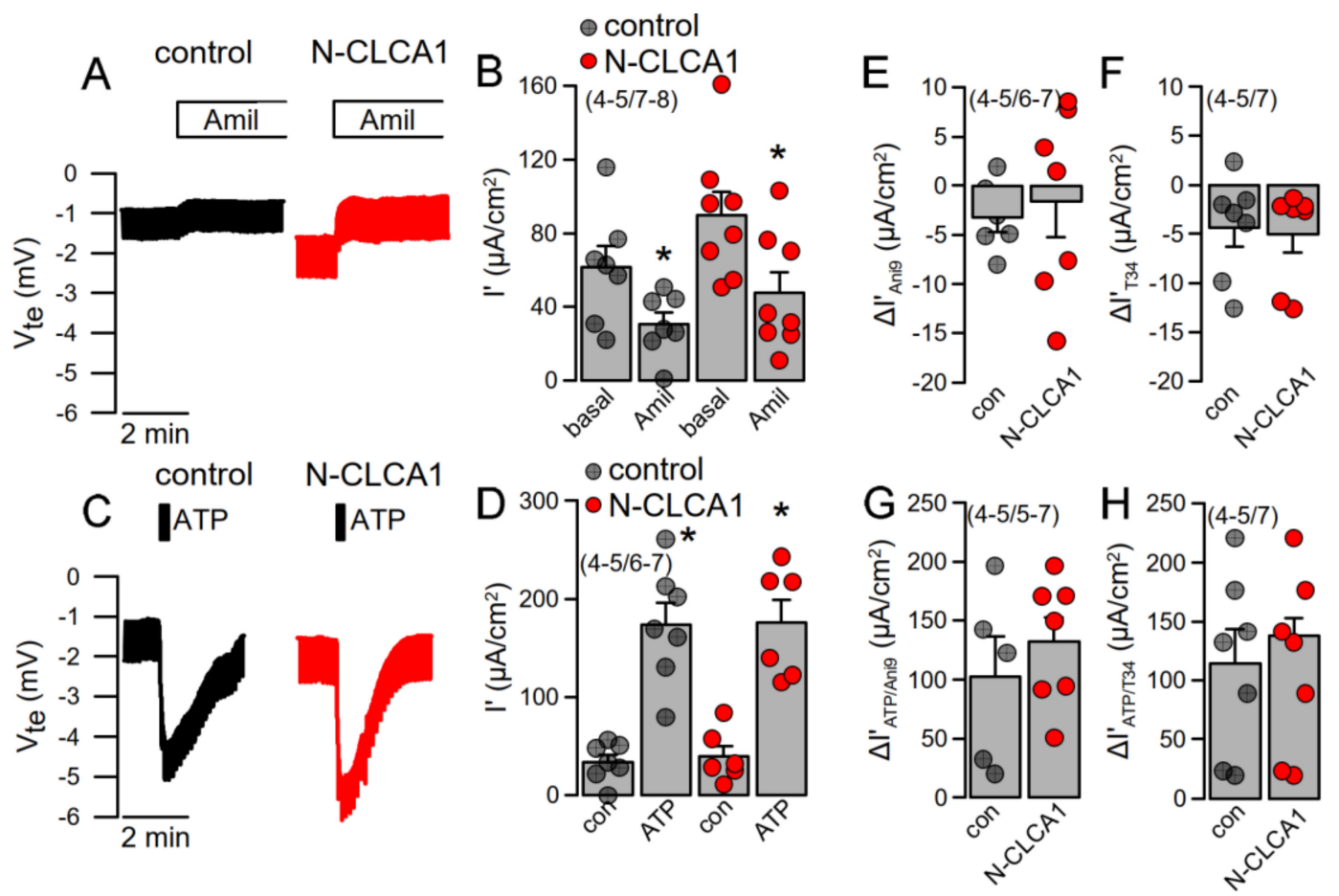

Figure 3. N-CLCA1 does not induce additional $\mathrm{Ca}^{2+}$-activated $\mathrm{Cl}^{-}$secretion in mouse tracheas. (A,B) Original Ussing chamber recording of the transepithelial voltages measured in mouse trachea under open circuit conditions and summary of the calculated equivalent short circuit current (Isc'). No significant changes in amiloride-sensitive $(10 \mu \mathrm{M}) \mathrm{Na}^{+}$absorption was detected by $24 \mathrm{~h}$ exposure to N-CLCA1. (C,D) No significant changes in ATP (luminal; $100 \mu \mathrm{M}$ )—induced negative voltage deflection and ATP-activated Isc' was detected by N-CLCA1. (E,F) N-CLCA1 did not induce an effect of Ani9 $(10 \mu \mathrm{M})$ or TRAM-34 $(100 \mathrm{nM})$ on basal currents. (G,H) Effects of ATP in the presence of luminal Ani9 or basolateral TRAM-34 (T34) were independent of N-CLCA1. Mean \pm SEM (number of animals/number of experiments). * - significant effect of amiloride and ATP $(p<0.05$; paired $t$-test).

Under control conditions, ATP activated only small ion currents in Calu3 cells. In contrast, ATP hyperpolarized the membrane voltage and clearly activated a whole cell $\mathrm{K}^{+}$ current in cells exposed to IL-13 (Figure S2F,G). Inhibition of KCNN4 by TRAM-34 abolished the ATP-induced hyperpolarization and induced a strong outward rectification (Figure S2F-H). Peak currents measured at the clamp voltage of $+100 \mathrm{mV}$ were similar in the absence or presence of TRAM-34. In the absence of TRAM-34, whole cell currents were dominated by KCNN4, while TMEM16A currents dominated in the presence of 
TRAM-34-i.e., in the absence of KCNN4 currents. In the absence of KCNN4 currents cells are depolarized which facilitates activation of voltage-dependent TMEM16A channels by increase in intracellular $\mathrm{Ca}^{2+}$. In contrast, in the absence of TRAM-34, $\mathrm{Ca}^{2+}$-dependent activation and hyperpolarization by KCNN4 inhibits activation of TMEM16A [26]. This is further supported in the human CF submucosal airway epithelial cell line 6CFSMEo-. This cell line demonstrates pronounced expression of both TMEM16A and KCNN4, but no or little expression of CFTR, CLCA1, and the potassium channel KCNQ1 (Figure S3A). Stimulation by ATP activated a whole cell $\mathrm{K}^{+}$current and hyperpolarized the membrane voltage, which was more pronounced than in Calu3 cells. The KCNN4 inhibitor TRAM-34 abolished hyperpolarization by ATP-dependent activation of KCNN4, but peak currents at $+100 \mathrm{mV}$ remained unchanged. The results demonstrate again a predominant activation of $\mathrm{Ca}^{2+}$-activated $\mathrm{K}^{+}$currents by ATP inducing pronounced hyperpolarization, which counteracts activation of TMEM16A [26] (Figure S3B,C). In contrast, TMEM16A is activated in the presence of TRAM-34 and the TMEM16A-blocker Ani9 fully inhibited ATP-activated whole cell currents (Figure S3D).

\subsection{Expression and Plasma Membrane Localization of TMEM16A Is Enhanced by IL-13 and N-CLCA1, Respectively}

Above data indicate an upregulation of TMEM16A expression under asthmatic conditions and by the cytokine IL-13 [16]. N-CLCA1, in contrast, did not induce expression of TMEM16A in Calu3 cells (Figure 4A). This is further supported by Western blotting of TMEM16A. IL-13 but not by CLCA1 enhanced expression of TMEM16A (Figure 4B). Immunofluorescence staining of TMEM16A demonstrated enhanced expression of TMEM16A upon treatment of Calu3 cells with the Th2-cytokine IL-13. CLCA1 did not increase the number of TMEM16A-positive cells but seemed to enhance membrane expression of TMEM16A (Figure 4C). Quantification of the immunofluorescence in the plasma membrane suggested an increase in plasma-membrane localization of TMEM16A by both IL-13 and N-CLCA1 (Figure 4D,E). We analyzed whole cell currents activated by ATP in the absence and presence of N-CLCA1. In the absence of N-CLCA1 very little current was activated by ATP (Figure S4). Upon exposure to N-CLCA1, cells were hyperpolarized by application of ATP, suggesting activation of KCNN4 $\mathrm{K}^{+}$channels. In the presence of TRAM-34 (T34), ATP no longer hyperpolarized cells and activated a more outwardly rectifying whole cell current, suggesting predominant activation of TMEM16A (Figure S4). Taken together, NCLCA1 increases KCNN4 currents, possibly by enhancing plasma membrane localization of TMEM16A, which has been shown earlier to increase intracellular $\mathrm{Ca}^{2+}$ signals elicited by ATP [27].

\subsection{TMEM16A Supports Expression of SPDEF, the Regulator of Goblet Cell Metaplasia}

RT-PCR analysis of SPDEF expression in Calu3 cells indicated upregulation by incubation with the cytokine IL-13 (Figure 5A,B). siRNA knockdown of TMEM16A inhibited upregulation of SPDEF by IL-13 suggesting a role Of TMEM16A for expression of SPDEF. Similar inhibition of SPDEF expression by siTMEM16A was observed by Western blotting of SPDEF protein (upper and lower bands indicate glycosylated and nonglycosylated protein, respectively) (Figure 5C). Moreover, densitometric quantification of the Western blots also indicated inhibition of SPDEF expression by the TMEM16A inhibitors niclosamide and Ani9 (Figure 5D). Taken together, TMEM16A expression and function controls expression of the master switch for goblet cell metaplasia, SPDEF [28-30]. 


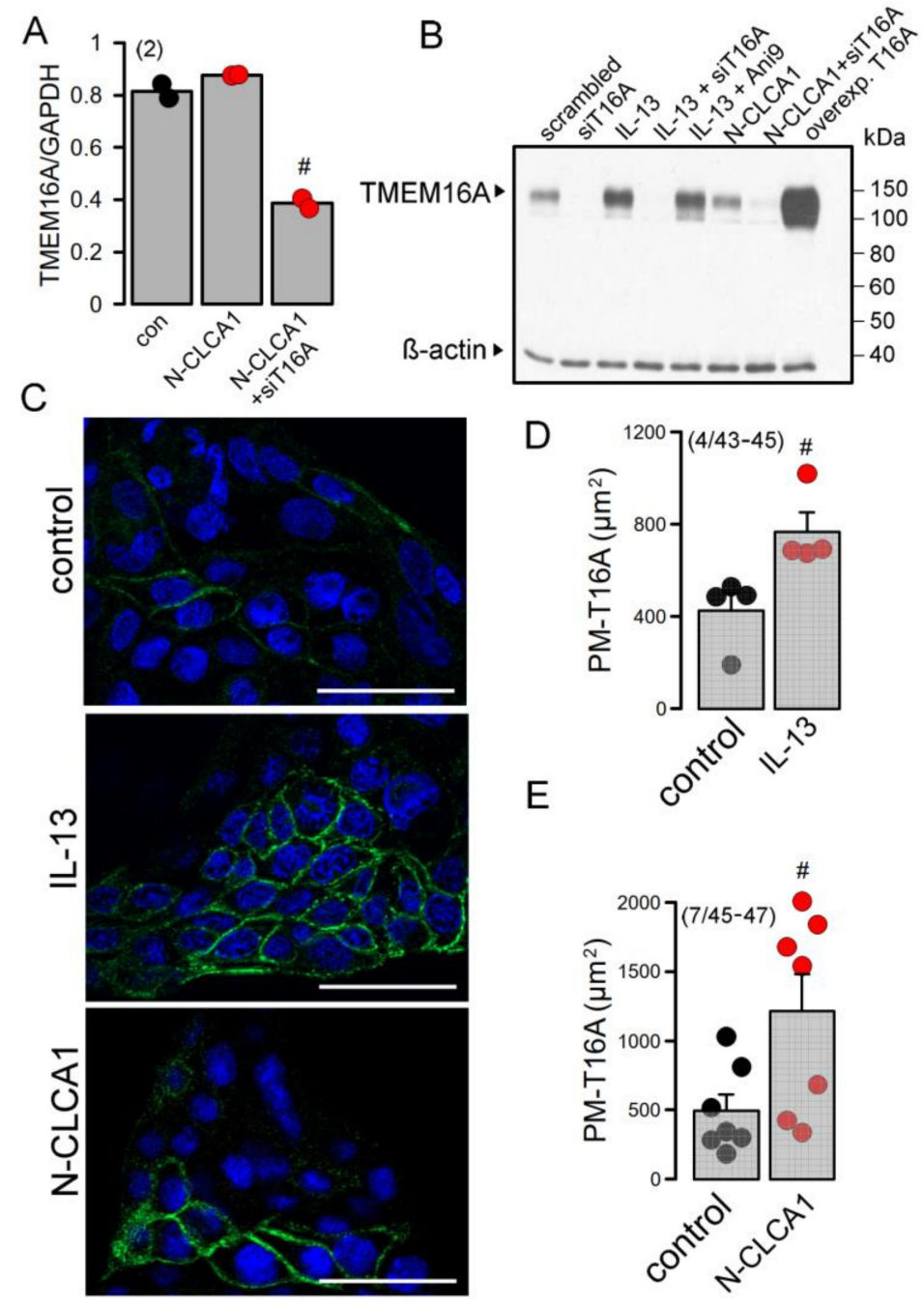

Figure 4. CLCA1 does not enhance expression of TMEM16A but stabilizes TMEM16A in the plasma membrane of Calu3 cells. (number of cover slips/number of cells)y. (A) Semiquantitative RT-PCR shows no increase in TMEM16A expression by exposure to N-CLCA1. (B) Western blot of TMEM16A indicates increase in expression by IL-13 but not by N-CLCA1. (C) Staining of TMEM16A in the plasma membrane indicates low expression in Calu3 cells. Exposure of Calu3 cells to IL-13 ( $20 \mathrm{ng} / \mathrm{mL})$ increases expression of TMEM16A. N-CLCA1 does not increase the number of Calu3 cells expressing TMEM16A, but rather enhances membrane expression of TMEM16A in some cells. Bars $=50 \mu \mathrm{m}$. (D) Quantification of TMEM16A plasma membrane staining in the absence or presence of IL-13. (number of cover slips/number of cells). (E) Quantification of TMEM16A plasma membrane staining in the absence or presence of CLCA1. (number of cover slips/number of cells). Mean \pm SEM \# significant difference when compared to control or control ( $p<0.05$; unpaired $t$-test). 

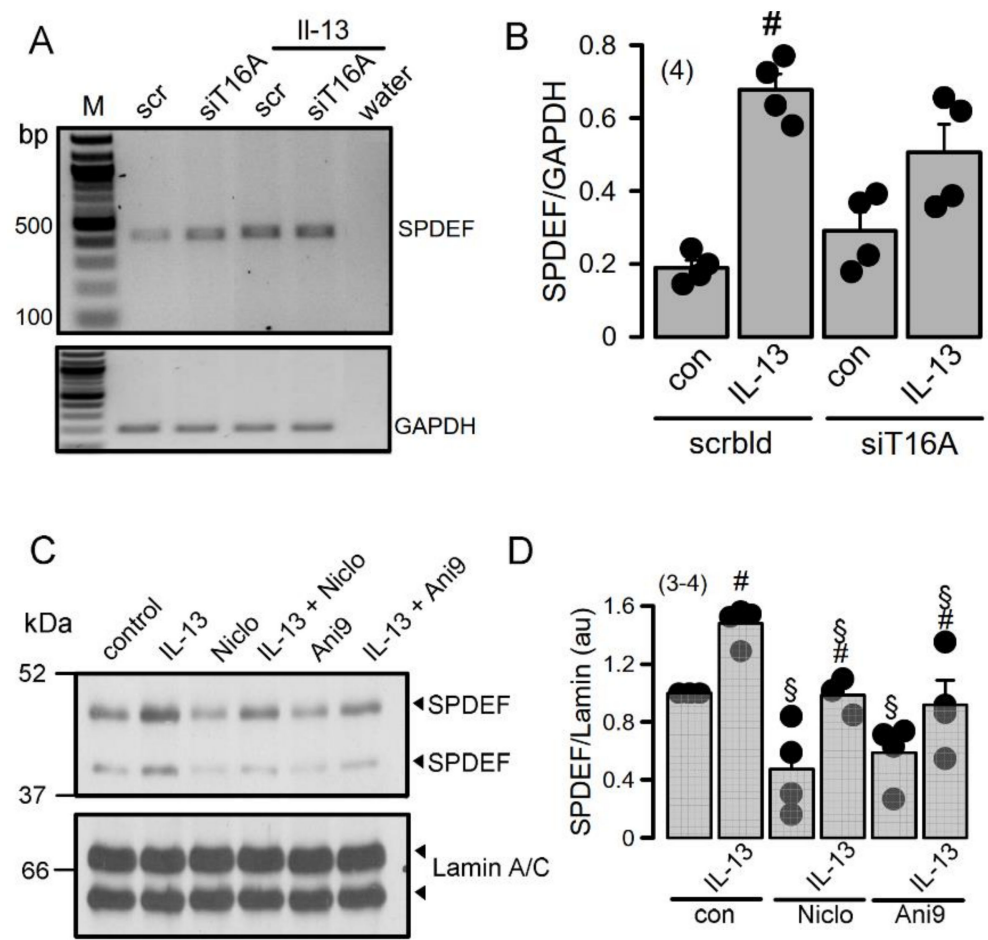

Figure 5. TMEM16A supports upregulation of the master switch for goblet cell metaplasia, SPDEF. (A,B) RT-PCR analysis suggests inhibition of SPDEF expression by siRNA-knockdown of TMEM16A. (number of experiments). (C,D) Western blots indicating inhibition of SPDEF expression by inhibitors of TMEM16A. (number of experiments). Mean \pm SEM. \#_-significant difference when compared to scrambled, control, and L-13, respectively ( $p<0.05$; unpaired $t$-test).

\subsection{CLCA1-Induced Mucus Production in Polarized BCi-NS1 Cells Is TMEM16A-Dependent}

The present and previous data [16] data suggest an important role of TMEM16A for IL-13 and CLCA1-induced mucus/MUC5AC production. We explored the role of TMEM16A/CLCA1 also in polarized grown BCi-NS1 human airway epithelial cells [16,31]. While expression of both TMEM16A and CLCA1 was very low in these cells, exposure of the cells to IL-13 increased expression of both proteins (Figure 6A). Interestingly, expression of TMEM16A was strongly reduced upon polarization of the cells, while expression of CLCA1 was upregulated (Figure 6B). Ussing chamber recordings under open circuit conditions demonstrated the typical negative voltage deflections upon stimulation with ATP, which were, however, not enhanced by IL-13 (Figure 6C,D). The basal properties of the BciNS1 cells were already reported in our previous study. The transepithelial resistance TEER $\left(\mathrm{R}_{\mathrm{te}}\right)$ was $>2 \mathrm{kVcm}^{2}$ and was not affected by treatment with IL-13. Amiloride sensitive Isc was $9.8 \mu \mathrm{A} / \mathrm{cm}^{2}$ for both control cells and cells stimulated with IL-13. Moreover, ATPeffects in the presence of Ani9 were similar in the absence or presence of IL-13 (Figure 6E). Exposure of the cells to N-CLCA1 upregulated mucus production, which was inhibited by simultaneous knockout of TMEM16A (siT16A, Figure 6F,G). The results obtained in these polarized airway epithelial cells confirm the important role of TMEM16A not only for IL-13-induced goblet cell metaplasia [16], but also demonstrate an important function of TMEM16A in CLCA1-induced mucus production. 

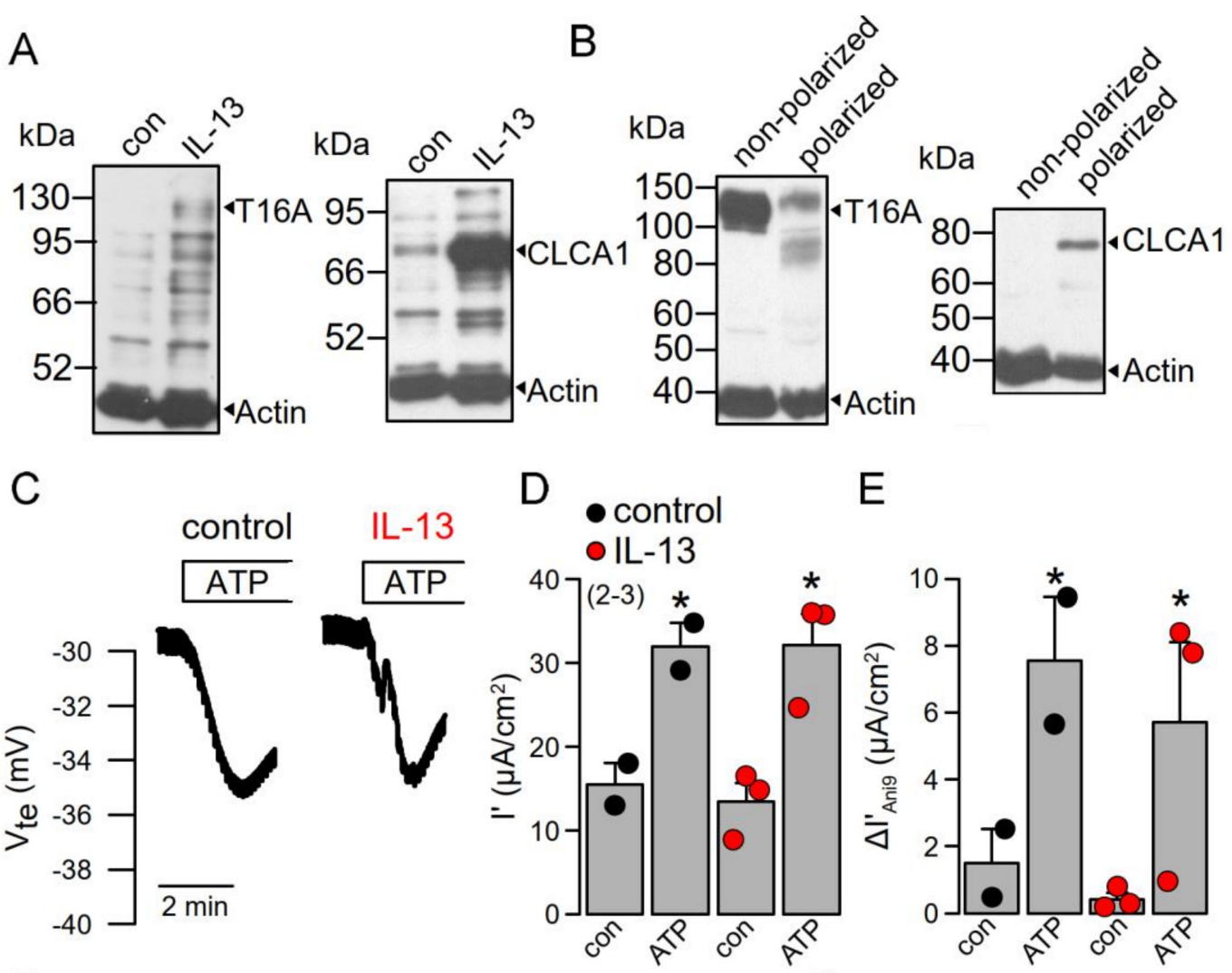

E

F

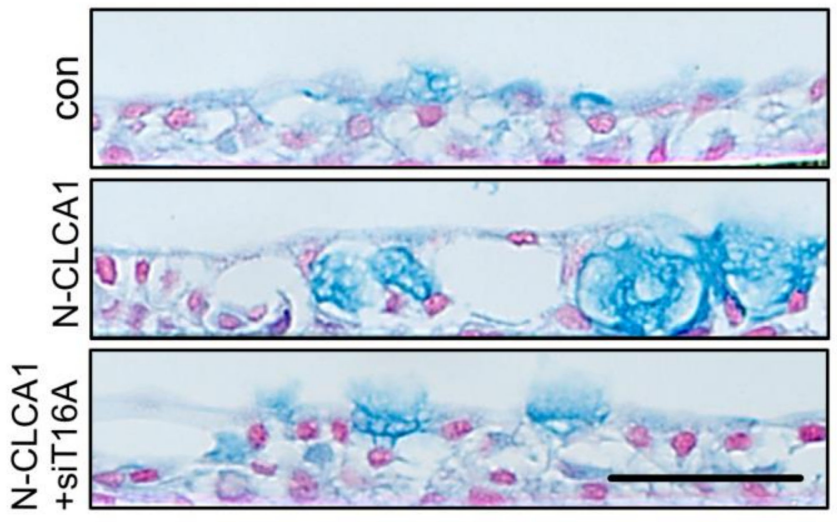

G
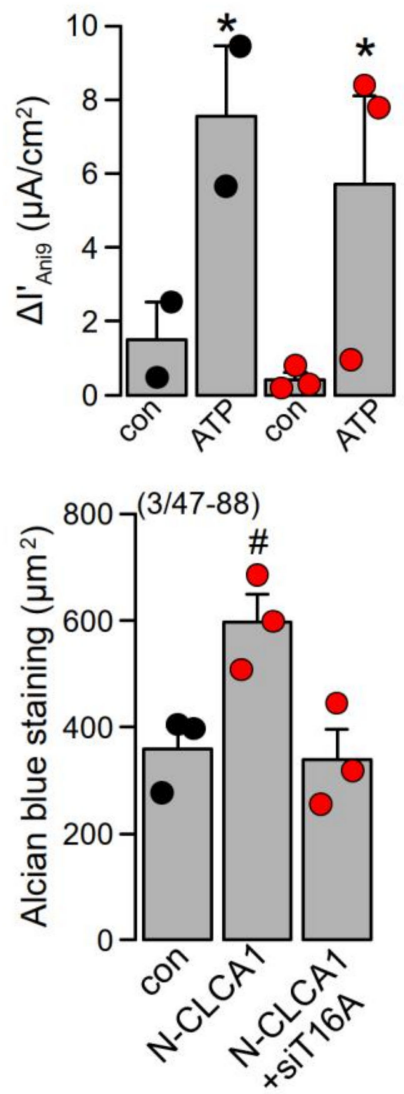

Figure 6. CLCA1-induced mucus production in polarized BCi-NS1 cells is TMEM16A-dependent. A,B) Western blot indicating upregulation of CLCA1 expression in BCi-NS1 cells exposed to IL-13 (20 ng/mL). Expression of TMEM16A was found to be attenuated in polarized grown cells (filter-grown ALI-cultures), when compared to nonpolarized (plastic-grown) cells. In contrast, CLCA1 expression was upregulated in ALI cultures. (number of experiments). (C,D) IL-13 does not enhance ATP-induced $(100 \mu \mathrm{M})$ negative voltage deflections and activation of short circuit currents (Isc). Activation of Isc was fully transient, i.e., the current returned to the baseline. (E) The effect of the TMEM16A inhibitor Ani9 (10 $\mu$ M) is not enhanced in IL-13 treated cells. (F,G) Individual examples and quantification of alcian blue staining in polarized BCi-NS1 cells under control conditions, after exposure to N-CLCA1 or in cells treated with N-CLCA1 and siTMEM16A. Mucus expression is enhanced in N-CLCA1-treated cells, but the effect of N-CLCA1 is blocked after knockdown of TMEM16A. (number of experiments). Scale bar $=50 \mu \mathrm{m}$. Mean \pm SEM. \# significant difference when compared to control $(p<0.05$; unpaired $t$-test). * significant activation by ATP $(p<0.05$; paired $t$-test $)$. 


\section{Discussion}

The calcium-activated chloride channel regulator 1 (CLCA1) was shown to be most upregulated gene transcript ( $>100$-fold) in a study with diisocyanate-induced asthmatic mice [32]. The ability of diisocyanate to induce CLCA1 was remarkable given the absence of TH2-type T cell cytokines IL-4 or IL-13. Because in this study the pro-asthmatic effects of diisocyanate were inhibited by crofelemer, the authors suggested a role of TMEM16Aupregulation of mucus and CLCA1. A role of TMEM16A for mucus production and mucus secretion was also suggested from our earlier studies $[5,16]$ and a number of other reports [3,4,15,33-35]. Additionally, the present data suggest a role of TMEM16A for mucus production induced by CLCA1 in polarized airway epithelial cells (Figure 6). The expression levels of TMEM16A in mouse airways and polarized human airway epithelia are very low $[7,12]$ and its contribution to $\mathrm{Ca}^{2+}$-activated $\mathrm{Cl}^{-}$secretion is rather limited (Figures 1 and 6). Low expression of TMEM16A may not be misinterpreted as a missing role in mucus secretion [7]. A number of previous reports demonstrate TMEM16A as a membrane tether of the endoplasmic reticulum and a regulator of spatial sub-membranous $\mathrm{Ca}^{2+}$ signals $[5,27,36]$. Typically, expression of $\mathrm{Ca}^{2+}$-regulating proteins such as IP3 receptors or $\mathrm{Ca}^{2+}$ influx channels is scarce in terminally differentiated cells but is often enhanced when cells start proliferating. As described in our previous reports, TMEM16A expression is largely enhanced in proliferating cells [37-39].

The role of TMEM16A for $\mathrm{Ca}^{2+}$-dependent $\mathrm{Cl}^{-}$secretion in the airways may have been overestimated in previous studies. The reduced ATP-induced $\mathrm{Cl}^{-}$secretion observed in the airways of TMEM16A-knockout mice $[40,41]$ is at least in part due to the compromised function of CFTR [8-13]. Moreover, the use of nonspecific inhibitors of TMEM16A such as $\mathrm{CaCCinhAO1}$, niclosamide, niflumic acid and others may also contribute to this overestimation. The present study also suggests that $\mathrm{Ca}^{2+}$-activated $\mathrm{KCNN} 4 \mathrm{~K}^{+}$channels are upregulated by Th2-dependent stimulation (IL-13, OVA) and are activated by purinergic stimulation, which hyperpolarizes the membrane voltage upon $\mathrm{Ca}^{2+}$-dependent stimulation and disables activation of TMEM16A (Figure 2, Figures S2-S4). Activation of KCNN4 is essential to maintain the electrical driving force for $\mathrm{Cl}^{-}$secretion during $\mathrm{Ca}^{2+}$-dependent stimulation. Thus, we would disagree with a recent report that claims inhibition of KCNN4 to reduce $\mathrm{Na}^{+}$absorption and to improve mucociliary clearance in patients with cystic fibrosis [42]. In fact, ASL in human airways relies essentially on submucosal gland secretion, which essentially need KCNN4. A number of papers indicate that basolateral $\mathrm{Ca}^{2+}$-activated SK4-like chloride channels are required for chloride secretion by the airway epithelium [43] [44-47]. Moreover, submucosal bicarbonate secretion also essentially requires activation of $\mathrm{Ca}^{2+}$-dependent SK4 potassium channels [48,49]. Inhibition of KCNN4 is therefore likely to worsen CF-lung disease.

An important finding of the present study is the impact of TMEM16A expression and the TMEM16A inhibitors niclosamide and Ani9- [14,50] on IL-13-induced expression of SPDEF. Airway epithelial SPDEF is a transcriptional regulator that integrates goblet cell differentiation and pulmonary Th2 inflammation [28-30]. This present observation may also help to explain why niclosamide had a clear inhibitory effect on mucus production in our previous study [51].

Accumulation of mucus in N-CLCA1-treated mice was an obvious finding of the present study (Figures 1 and 2). CLCA1 may have enhanced membrane expression of TMEM16A and thereby may have increased mucus secretion. However, CLCA1 may have also contributed to unfolding and expansion of airway mucus, similar to unfolding of intestinal mucus $[25,52]$. Although CLCA1 was proposed to induce this effect by activating CaCC/TMEM16A in vitro [16-21,53], our present in vivo data do not indicate an upregulation of TMEM16A currents in mouse trachea. Thus, our data agree with other in vivo studies that indicate (i) no contribution of CLCA1 chloride conductance in mouse airways [24] and (ii) no inhibition of CLCA1-indued mucus expansion by TMEM16A channel blockers in mouse intestine [25]. Thus, results obtained in vitro may not necessarily reflect the situation in vivo. Along this line, we may refer to our previous observations that 
indicate a remarkable difference in functional regulation of TMEM16A, when comparing endogenous TMEM16A with overexpressed TMEM16A [54,55]. Data on the regulation of TMEM16A by CLCA1 obtained exclusively in heterologous expression systems may not necessarily apply in vivo. In conclusion, the regulator of TMEM16A, CLCA1, is a potent stimulus for mucus secretion and, surprisingly, for mucus production. However, CLCA1 had no measurable effect on TMEM16A-dependent $\mathrm{Cl}^{-}$transport in naïve mouse airways and differentiated human airway epithelia, probably due to its low expression in fluid secretory cells. We speculate that activation of TMEM16A will probably not compensate for defective $\mathrm{Cl}^{-}$secretion in cystic fibrosis.

\section{Materials and Methods}

\subsection{Animals and Treatments}

Allergen challenge of mice has been described previously [56]. In brief, mice were sensitized to ovalbumin (OVA; Sigma-Aldrich, St. Louis, MO, USA) by intraperitoneal (I.P.) injection of $100 \mu \mathrm{g}$ OVA in $100 \mu \mathrm{L}$ Aluminum Hydroxide Gel Adjuvant (InvivoGen, San Diego, CA, USA) on days 0 and 14. At days 21 to 23, mice were anesthetized (ketamine90-120 $\mathrm{mg} / \mathrm{kg}$ and xylazine $-6-8 \mathrm{mg} / \mathrm{kg}$ ) and challenged to OVA by intratracheal (I.T.) instillation of $50 \mu \mathrm{g}$ OVA in $100 \mu \mathrm{L}$ saline. Control mice were sham-sensitized with aluminum hydroxide gel and challenged to saline by I.T. instillation. Allergen reaction was allowed to develop for $72 \mathrm{~h}$. CLCA1-conditioned media (N-CLCA1; $100 \mu \mathrm{L}$; preparation described below) was administered to control or OVA-challenged animals by I.T. instillation $24 \mathrm{~h}$ before sacrificing the animals. Control I.T. instillation was performed with mock-conditioned media. All animal experiments complied with the reporting of in vivo experiments guidelines and were carried out in accordance with the United Kingdom Animals Act, 1986, and associated guidelines, and EU Directive 2010/63/EU for animal experiments. All animal experiments were approved by the local Ethics Committee of the Government of Unterfranken/Wurzburg (AZ: 55.2-2532-2-1359-15) and were conducted according to the guidelines of the American Physiologic Society and German Law for the Welfare of Animals.

\subsection{Cell Culture and Treatments}

All cells were grown at $37^{\circ} \mathrm{C}$ in a humidified atmosphere with $5 \% \mathrm{CO}_{2}$. Calu3 human airway epithelial cells were grown in DMEM/Ham's F-12 with L-Glutamine medium supplemented with $10 \%(v / v)$ fetal bovine serum (FBS), 1\% (v/v) L-glutamine $200 \mathrm{mM}$ and $1 \%(v / v)$ HEPES 1M (all from Capricorn Scientific, Ebsdorfergrund, Germany). Human embryonic kidney HEK293T cells were grown in DMEM low glucose medium supplemented with 10\% (v/v) FBS and 1\% (v/v) L-glutamine $200 \mathrm{mM}$ (all from Capricorn Scientific, Ebsdorfergrund, Germany).

Construction of expression plasmids has been described previously [57]. In brief, CLCA1 was cloned from human colon and ligated into a pcDNA3.1 vector. For conditioned media preparation, HEK293T cells were seeded at 500,000 cells per 6 well and next day transfected with empty pcDNA3.1 (mock) or hCLCA1 plasmids using standard protocols for Lipofectamine 3000 (Invitrogen, Carlsbad, CA, USA). After $6 \mathrm{~h}$, the medium was changed to serum-free media (Opti-MEM Reduced Serum Medium (Gibco/Thermo Fisher Scientific, Waltham, MA, USA)) and $24 \mathrm{~h}$ later the supernatants-control or enriched in secreted CLCA1 protein (N-CLCA1) were collected. BCi-NS1 cells (kindly provided by Prof. R. Crystal, Weill Cornell Medical College, New York, NY, USA) were cultured in supplemented Bronchial Epithelial Cell Growth Medium (Lonza, Basel, Switzerland). For polarization, BCi-NS1 cells were seeded onto permeable supports with a pore size of $0.4 \mu \mathrm{m}$ (Snapwell \#3801, Corning, New York, NY, USA) in an air-liquid interface by seeding 300,000 cells on human type IV collagen (Sigma-Aldrich, St. Louis, Missouri, USA) — coated inserts. Cells were maintained in a media consisting of 1:1 DMEM:Ham's F12 supplemented with 10\% (v/v) FBS, 1\% (v/v) P/S, 0.5\% (v/v) Amphotericin B and 0.1\% (v/v) Gentamycin (all from Capricorn Scientific, Ebsdorfergrund, Germany). On the following day, the serum 
was replaced with $2 \%(v / v)$ of serum-substitute Ultroser G (Pall Life Sciences, New York, NY, USA). On the second day after seeding, the media was removed from the upper compartment to expose the apical surface to air and to establish an air-liquid interface (ALI). Cells were grown for 28 days on filters, and transepithelial resistances (TEER) were measured regularly, which was in the range as described earlier [16].

Cells were treated with IL-13 (20 ng/mL; Enzo Life Sciences, Lörrach, Germany) for $72 \mathrm{~h}$ in Opti-MEM, and treatment was refreshed every day in the absence or presence of the inhibitors Ani9 and Niclosamide-ethanolamine (both $1 \mu \mathrm{M}$; Sigma-Aldrich, St. Louis, Missouri, USA). Treatment with mock- or CLCA1-conditioned media was applied for 24-48 $\mathrm{h}$. Treatment of polarized BCi cells was performed both in the basolateral media and by adding $100 \mu \mathrm{L}$ to the apical compartment. Knockdown of TMEM16A was performed by transfection of siRNA against TMEM16A (5-GGUUCCCAGCCUACCUCACUAACUU-3; Invitrogen, Carlsbad, California, USA) using standard protocols for Lipofectamine 3000 . Scrambled siRNA (Silencer ${ }^{\circledR}$ Select Negative Control siRNA \#1, Ambion, Austin, TX, USA) was transfected as negative control. Knockdown of TMEM16A was validated as reported earlier [16]. All experiments were performed 48-72 h after transfection.

\subsection{RT-PCR}

For semiquantitative RT-PCR total RNA from tracheal epithelial cells, lung tissue, Calu3 or $6 \mathrm{CFSMEo}^{-}$cells was isolated using NucleoSpin RNA II columns (MachereyNagel, Düren, Germany). Total RNA ( $0.5 \mu \mathrm{g} / 25 \mu \mathrm{l}$ reaction) was reverse-transcribed using random primers (Promega, Mannheim, Germany) and M-MLV Reverse Transcriptase RNase H Minus (Promega, Mannheim, Germany). Each RT-PCR reaction contained sense $(0.5 \mu \mathrm{M})$ and antisense primers $(0.5 \mu \mathrm{M})$ (Table 1$), 0.5 \mu \mathrm{l}$ cDNA and GoTaq Polymerase (Promega, Mannheim, Germany). After $2 \mathrm{~min}$ at $95^{\circ} \mathrm{C}$, cDNA was amplified (targets $30-35$ cycles, reference Gapdh 25 cycles) for $30 \mathrm{~s}$ at $95^{\circ} \mathrm{C}, 30 \mathrm{~s}$ at $56^{\circ} \mathrm{C}$ and $1 \mathrm{~min}$ at $72^{\circ} \mathrm{C}$. PCR products were visualized by loading on Midori Green Xtra (Nippon Genetics Europe) containing agarose gels and analyzed using Image J 1.52r (NIH, Bethesda, MD, USA).

Table 1. Primers used for PCR.

\begin{tabular}{|c|c|c|}
\hline Gene Accession Number & Primer & Size (bp) \\
\hline Mouse Tmem16a & s: 5'-GTGACAAGACCTGCAGCTAC & \multirow{2}{*}{406} \\
\hline NM_001242349.2 & as: $5^{\prime}$-GCTGCAGCTGTGGAGATTC & \\
\hline Human TMEM16A & s: 5'-CGACTACGTGTACATTTTCCG & \multirow{2}{*}{445} \\
\hline NM_018043.7 & as: 5'-GATTCCGATGTCTTTGGCTC & \\
\hline Mouse Cftr & s: 5'-GAATCCCCAGCTTATCCACG & \multirow{2}{*}{544} \\
\hline NM_021050.2 & as: 5'-CTTCACCATCATCTTCCCTAG & \\
\hline Human CFTR & s: 5'-CGACTACGTGTACATTTTCCG & \multirow{2}{*}{568} \\
\hline NM_000492.4 & as: 5'-GCTCTTGTGGACAGTAATATATCG & \\
\hline Human CLCA1 & s: 5'-GGGGCCATTTAAGAGTTCTG & \multirow{2}{*}{379} \\
\hline NM_001285.4 & as: 5'-CTCTCCACAGTTGCCCATC & \\
\hline Mouse Slc26a9 & s: 5'-CATTTGCTGCGCTCTCTCAG & \multirow{2}{*}{568} \\
\hline NM_177243.4 & as: 5'-CСТCTTCTCCTGCTTCCGG & \\
\hline Mouse Kcnn4 & s: 5'-GAATCAGCCACAGTGTGTC & \multirow{2}{*}{515} \\
\hline NM_008433.4 & as: $5^{\prime}$-CCTCCTTTGTCTTATTGTGG & \\
\hline Human KCNN4 & s: 5'-GATTTAGGGGCGCCGCTGAC & \multirow{2}{*}{405} \\
\hline NM_002250.3 & as: 5'-CTTGCCCCACATGGTGCCC & \\
\hline
\end{tabular}


Table 1. Cont.

\begin{tabular}{ccc}
\hline Gene Accession Number & Primer & Size (bp) \\
\hline Human KCNQ1 & s: 5'-CCACGGGGACTCTCTTCTG & 505 \\
NM_000218.3 & as: 5'-GGCACCTTGTCCCCATAG & 295 \\
Mouse Muc5ac & $\begin{array}{c}\text { s: 5'-CACCAAAGACAGCAGATCATC } \\
\text { as: 5'-GTTCTGAGGACTCTGCATGG }\end{array}$ & \multirow{2}{*}{423} \\
\hline HM_010844.3 & $\begin{array}{l}\text { s: 5'-GTGCTCAAGGACATCGAGAC } \\
\text { as: 5'-CCTAATGAAGCGGCCATAGC }\end{array}$ & 200 \\
\hline NM_012391.3 & s: 5'-GTATTGGGCGCCTGGTCAC & \multirow{2}{*}{ as: 5'-CTCCTGGAAGATGGTGATGG } \\
NMan Mouse Gapdh &
\end{tabular}

\subsection{Transepithelial Ussing Chamber Recordings}

Animals were sacrificed by cervical dislocation and isolated tracheas were cleaned, sectioned and kept in ice-cold standard bicarbonate-free Ringer's solution (in $\mathrm{mM}: \mathrm{NaCl}$ $145, \mathrm{KH}_{2} \mathrm{PO}_{4} 0.4, \mathrm{~K}_{2} \mathrm{HPO}_{4} \bullet 3 \mathrm{H}_{2} 01$. 6 , Glucose $5, \mathrm{MgCl}_{2} \bullet 6 \mathrm{H}_{2} 0$ 1, Ca-Gluconate $1 \mathrm{H}_{2} 0$ 1.3; $\mathrm{pH}$ 7.4). Tissues were mounted into Ussing chambers in supports with a circular aperture of $0.177 \mathrm{~cm}^{2}$. Polarized cell inserts were mounted onto supports with a circular aperture of $1.13 \mathrm{~cm}^{2}$. Luminal and basolateral sides of the epithelia were perfused continuously at a rate of $5 \mathrm{~mL} / \mathrm{min}$ with standard bicarbonate-free Ringer's solution \pm compounds (Amiloride $10 \mu \mathrm{M}$, apical; Tram34 100 or $300 \mathrm{nM}$, basolateral; Ani9 $10 \mu \mathrm{M}$, apical; ATP $100 \mu \mathrm{M}$, apical; all from Sigma-Aldrich, St. Louis, Missouri, USA). Luminal and basolateral solutions were heated to $37{ }^{\circ} \mathrm{C}$ using a water jacket. Experiments were carried out under open-circuit conditions. Data were continuously collected using PowerLab software (AD Instruments, Spechbach, Germany). Values for transepithelial voltages $\left(V_{\text {te }}\right)$ were referred to the serosal side of the epithelia. Transepithelial resistances $\left(\mathrm{R}_{\mathrm{te}}\right)$ were determined by applying short $(1 \mathrm{~s})$ current pulses $(\Delta \mathrm{I}=0.5 \mu \mathrm{A})$. Typically, the transepithelial resistance was between 45 and $65 \Omega \mathrm{cm}^{2}$ and was not changed by application of CLCA1. $R_{\text {te }}$ and equivalent short circuit currents (I'sc) were calculated according to Ohm's law $\left(\mathrm{R}_{\mathrm{te}}=\Delta \mathrm{V}_{\mathrm{te}} / \Delta \mathrm{I}\right.$, Isc $\left.=\mathrm{V}_{\mathrm{te}} / \mathrm{R}_{\mathrm{te}}\right)$.

\subsection{Western Blotting}

Protein was isolated from cells using a lysis buffer containing $25 \mathrm{mM}$ Tris- $\mathrm{HCl} \mathrm{pH}$ 7.4, $150 \mathrm{mM} \mathrm{NaCl}, 1 \mathrm{mM}$ EDTA, 5\% glycerol, $0.43 \%$ Nonidet P-40, $100 \mathrm{mM}$ dithiothreitol (both from PanReac AppliChem, Barcelona, Spain) and 1× protease inhibitor mixture (Roche, Basel, Switzerland). For supernatant protein precipitation, the trichloroacetic acid (TCA) method was used. Proteins were then separated by $8.5 \%$ SDS-PAGE and transferred to a PVDF membrane (GE Healthcare, Munich, Germany). Membranes were incubated overnight at $4{ }^{\circ} \mathrm{C}$ with primary antibodies: rabbit anti-TMEM16A (\#ab64085, Abcam, Cambridge, UK; 1:500 in 1\% (w/v) NFM/TBS-T), rabbit anti-CLCA1 (\#ab180851, Abcam; 1:1000 in 3\% (w/v) NFM/TBST-T), mouse anti-(S)PDEF(G10) (\#sc-166846, Santa Cruz Biotechnology; 1:250 in 3\% (w/v) NFM/TBST-T) and rabbit anti-KCNN4 (\#APC064, Alomone Labs, Jerusalem, Israel; 1:500 in 3\% (w/v) NFM/TBST-T). The antibodies rabbit anti-Actin (\#A2066; Sigma-Aldrich, St. Louis, Missouri, USA; 1:10 000 in 5\% (w/v) NFM/TBS-T), rabbit anti-Lamin A/C (\#sc-20681, Santa Cruz Biotechnology, Dallas, TX, USA; $1: 60,000$ in 3\% (w/v) NFM/TBST-T) and rabbit anti-Na+/K+-ATPase (\#sc-28800, Santa Cruz Biotechnology; 1:1500 in 5\% (w/v) NFM/TBST-T) were used as loading controls. Membranes were then incubated with horseradish peroxidase (HRP)-conjugated goat anti-rabbit or sheep anti-mouse secondary antibodies at room temperature for $2 \mathrm{~h}$ and immunoreactive signals were visualized using a SuperSignal HRP Chemiluminescence Substrate detection kit (\#34577; Thermo Fisher Scientific, Waltham, MA, USA).

\subsection{Immunocytochemistry}

For TMEM16A staining in Calu3 airway cells, cells seeded onto glass coverslips were fixed with a pre-cooled 3:1 mix of methanol:acetone for $10 \mathrm{~min}$ at $-20^{\circ} \mathrm{C}$, washed in PBS 
with $\mathrm{Ca}^{2+}$ and $\mathrm{Mg}^{2+}\left(\mathrm{PBS}^{++}\right)$, blocked with $5 \% \mathrm{BSA} \mathrm{PBS}^{++}$for $30 \mathrm{~min}$ at room temperature, incubated with rabbit anti-TMEM16A antibody (1:100 in 1\%BSA/PBS ${ }^{++}$; \#ab64085, Abcam, Cambridge, UK) for $1 \mathrm{~h}$ at $37^{\circ} \mathrm{C}$, washed, incubated with Alexa Fluor 488-labeled donkey anti-mouse IgG (1:400 in 1\%BSA/PBS ${ }^{++}$, Invitrogen, Carlsbad, California, USA) and counterstained with Hoe33342 (1:200) for $1 \mathrm{~h}$ at room temperature. Cells were then washed and mounted in fluorescence mounting medium. Plasma membrane (PM) staining was quantified using ImageJ and Zen. The quantitative analysis was performed by measuring the fluorescence intensity in the region of interest (ROI). ROIs are reflected by the plasma membrane and were detected by the analysis software. The settings for excitation and exposure time were identical for all measurements.

\subsection{Mucus Staining in Polarized Cells}

BCi cells polarized in permeable supports were fixed in 4\% PFA/PBS for $20 \mathrm{~min}$ at room temperature and embedded in paraffin. Paraffin cuts of $5 \mu \mathrm{m}$ were deparaffinized, stained with standard Alcian blue solution and counterstained with Nuclear Fast Red solution (Sigma-Aldrich, St. Louis, Missouri, USA). After dehydration and clearing steps, sections were mounted in DePeX mounting medium (SERVA Electrophoresis, Heidelberg, Germany). Stains were assessed by light microscopy. Mucus-stained (blue) areas were determined using ImageJ.

\subsection{Mucus Ctaining in Lungs}

Mouse lungs and tracheas were fixed by transcardial perfusion and lung perfusion with $4 \%$ paraformaldehyde in PBS. Tissues were incubated overnight in fixative solution and then embedded in paraffin. Paraffin-embedded sections of $5 \mu \mathrm{m}$ were deparaffinized, stained with standard Alcian blue solution and counterstained with Nuclear Fast Red solution (Sigma-Aldrich, Darmstadt, Germany). After dehydration and clearing steps, whole mouse lungs sections were mounted in DePeX mounting medium (SERVA Electrophoresis, Heidelberg, Germany). Stains were assessed by light microscopy and determined using ImageJ.

\subsection{Patch Clamp}

Cells were patch clamped when grown on coated glass coverslips. Coverslips were mounted in a perfused bath chamber on the stage of an inverted microscope (IM35, Zeiss) and kept at $37^{\circ} \mathrm{C}$. Patch pipettes were filled with a cytosolic-like solution containing (in $\mathrm{mM}$ ): $\mathrm{KCl} 30$, K-Gluconate 95, $\mathrm{NaH}_{2} \mathrm{PO}_{4} 1.2, \mathrm{Na}_{2} \mathrm{HPO}_{4}$ 4.8, EGTA 1, Ca-Gluconate 0.758, $\mathrm{MgCl}_{2}$ 1.03, D-Glucose 5, ATP 3; pH 7.2. The intracellular (pipette) $\mathrm{Ca}^{2+}$ activity was $0.1 \mu \mathrm{M}$. The bath was perfused continuously with standard bicarbonate-free Ringer's solution (in mM: $\mathrm{NaCl} 145, \mathrm{KH}_{2} \mathrm{PO}_{4} 0.4, \mathrm{~K}_{2} \mathrm{HPO}_{4} 1.6$, Glucose 5, $\mathrm{MgCl}_{2}$ 1, Ca-Gluconate 1.3) at a rate of $8 \mathrm{~mL} / \mathrm{min}$. Patch pipettes had an input resistance of 2-5 $\mathrm{M} \Omega$ and whole cell currents were corrected for serial resistance. Currents were recorded using a patch clamp amplifier EPC9, and PULSE software (HEKA, Lambrecht, Germany) as well as Chart software (AD Instruments, Spechbach, Germany). Cells were stimulated with $1 \mu \mathrm{M}$ ATP in the absence and presence of TRAM34. In regular intervals, membrane voltage $(V c)$ was clamped in steps of $20 \mathrm{mV}$ from -100 to $+100 \mathrm{mV}$ from a holding voltage of $-100 \mathrm{mV}$. Current density was calculated by dividing whole cell currents by cell capacitance.

\subsection{Materials and Statistical Analysis}

All compounds used were of highest available grade of purity and were bought from Sigma-Aldrich (St. Louis, Missouri, USA), unless indicated otherwise. Data are shown as individual traces/representative images and/or as summaries with mean values $\pm \mathrm{SEM}$, with the respective number of experiments given in each figure legend. For statistical analysis, paired or unpaired Student's t-test or ANOVA were used as appropriate. A $p$-value of $<0.05$ was accepted as a statistically significant difference. 
Supplementary Materials: The following are available online at https: / www.mdpi.com/article/ 10.3390/ijms22105133/s1, Supplementary Figure S1. CLCA1 produced in HEK293 cells, Figure S2: Upregulation of KCNN4 channels in asthma, Supplementary Figure S3. Activation of TMEM16A and KCNN4 in 6CFSMEo- human submucosal glands, Supplementary Figure S4. Activation of whole cell currents by N-CLCA1.

Author Contributions: R.C., J.O., R.S. and K.K. designed the research; R.C., J.O. and R.S. performed the experiments; R.C., J.O., R.S. and K.K. analyzed data; R.C., J.O., R.S. and K.K. wrote the manuscript. All authors have read and agreed to the published version of the manuscript.

Funding: Supported by UK CF Trust SRC013, DFG KU756/14-1, DFG project number 387509280 , SFB 1350 (project A3) and Gilead Stiftung.

Institutional Review Board Statement: All animal experiments complied with the reporting of in vivo experiments guidelines and were carried out in accordance with the United Kingdom Animals Act, 1986, and associated guidelines, and EU Directive 2010/ 63/EU for animal experiments. All animal experiments were approved by the local Ethics Committee of the Government of Unterfranken/Wurzburg (AZ: 55.2-2532-2-1359-15) and were conducted according to the guidelines of the American Physiologic Society and German Law for the Welfare of Animals.

Informed Consent Statement: Not applicable.

Data Availability Statement: Not applicable.

Acknowledgments: The technical assistance by Patricia Seeberger is greatly appreciated.

Conflicts of Interest: The authors declare no conflict of interest.

\section{References}

1. Pedemonte, N.; Galietta, L.J. Structure and Function of TMEM16 Proteins (Anoctamins). Physiol. Rev. 2014, 94, 419-459. [CrossRef]

2. Galietta, L.J.; Pagesy, P.; Folli, C.; Caci, E.; Romio, L.; Costes, B.; Nicolis, E.; Cabrini, G.; Goossens, M.; Ravazzolo, R.; et al. IL-4 Is a Potent Modulator of Ion Transport in the Human Bronchial Epithelium In Vitro. J. Immunol. 2002, 168, 839-845. [CrossRef] [PubMed]

3. Huang, F.; Zhang, H.; Wu, M.; Yang, H.; Kudo, M.; Peters, C.J.; Woodruff, P.G.; Solberg, O.D.; Donne, M.L.; Huang, X.; et al. Calcium-activated chloride channel TMEM16A modulates mucin secretion and airway smooth muscle contraction. Proc. Natl. Acad. Sci. USA 2012, 109, 16354-16359. [CrossRef] [PubMed]

4. Kondo, M.; Tsuji, M.; Hara, K.; Arimura, K.; Yagi, O.; Tagaya, E.; Takeyama, K.; Tamaoki, J. Chloride ion transport and overexpression of TMEM16A in a guinea pig asthma model. Clin. Exp. Allergy 2017, 47, 795-804. [CrossRef] [PubMed]

5. Benedetto, R.; Cabrita, I.; Schreiber, R.; Kunzelmann, K. TMEM16A is indispensable for basal mucus secretion in airways and intestine. FASEB J. 2019, 33, 4502-4512. [CrossRef] [PubMed]

6. Kunzelmann, K.; Ousingsawat, J.; Cabrita, I.; Doušová, T.; Bähr, A.; Janda, M.; Schreiber, R.; Benedetto, R. TMEM16A in Cystic Fibrosis: Activating or Inhibiting? Front. Pharm. 2019, 29, 3. [CrossRef]

7. Simoes, F.B.; Quaresma, M.C.; Clarke, L.A.; Silva, I.A.; Pankonien, I.; Railean, V.; Kmit, A.; Amaral, M.D. TMEM16A chloride channel does not drive mucus production. Life Sci. Alliance 2019, 2, e201900462. [CrossRef] [PubMed]

8. Namkung, W.; Finkbeiner, W.E.; Verkman, A.S. CFTR-Adenylyl Cyclase I Association Is Responsible for UTP Activation of CFTR in Well-Differentiated Primary Human Bronchial Cell Cultures. Mol. Biol. Cell 2010, 21, 2639-2648. [CrossRef]

9. Billet, A.; Hanrahan, J.W. The secret life of CFTR as a calcium-activated chloride channel. J. Physiol 2013, 591, 5273-5278. [CrossRef]

10. Benedetto, R.; Ousingsawat, J.; Cabrita, I.; Pinto, M.; Lerias, J.; Wanitchakool, P.; Schreiber, R.; Kunzelmann, K. Plasma membrane localized TMEM16 Proteins are Indispensable for expression of CFTR. J. Mol. Med. 2019, 97, 711-722. [CrossRef] [PubMed]

11. Lerias, J.; Pinto, M.; Benedetto, R.; Schreiber, R.; Amaral, M.; Aureli, M.; Kunzelmann, K. Compartmentalized crosstalk of CFTR and TMEM16A (ANO1) through EPAC1 and ADCY1. Cell Signal. 2018, 44, 10-19. [CrossRef] [PubMed]

12. Benedetto, R.; Ousingsawat, J.; Wanitchakool, P.; Zhang, Y.; Holtzman, M.J.; Amaral, M.; Rock, J.R.; Schreiber, R.; Kunzelmann, K. Epithelial Chloride Transport by CFTR Requires TMEM16A. Sci. Rep. 2017, 7, 12397. [CrossRef] [PubMed]

13. Park, J.H.; Ousingsawat, J.; Cabrita, I.; Bettels, R.E.; Große-Onnebrink, J.; Schmalstieg, C.; Biskup, S.; Reunert, J.; Rust, S.; Schreiber, R.; et al. TMEM16A deficiency: A potentially fatal neonatal disease resulting from impaired chloride currents. J. Med. Genet. 2020, 58, 247-253. [CrossRef] [PubMed]

14. Miner, K.; Labitzke, K.; Liu, B.; Elliot, R.; Wang, P.; Henckels, K.; Gaida, K.; Elliot, R.; Chen, J.J.; Liu, L.; et al. Drug Repurposing: The Anthelmintics Niclosamide and Nitazoxanide Are Potent TMEM16A Antagonists That Fully Bronchodilate Airways. Front. Pharm. 2019, 10, 51. [CrossRef] [PubMed]

15. Lin, J.; Jiang, Y.; Li, L.; Liu, Y.; Tang, H.; Jiang, D. TMEM16A mediates the hypersecretion of mucus induced by Interleukin-13. Exp. Cell Res. 2015, 334, 260-269. [CrossRef] [PubMed] 
16. Cabrita, I.; Benedetto, R.; Wanitchakool, P.; Lerias, J.; Centeio, R.; Ousingsawat, J.; Schreiber, R.; Kunzelmann, K. TMEM16A Mediated Mucus Production in Human Airway Epithelial Cells. Am. J. Respir. Cell Mol. Biol. 2020. [CrossRef] [PubMed]

17. Patel, A.C.; Brett, T.J.; Holtzman, M.J. The role of CLCA proteins in inflammatory airway disease. Annu. Rev. Physiol. 2009, 71, 425-449. [CrossRef] [PubMed]

18. Zhou, Y.; Dong, Q.; Louahed, J.; Dragwa, C.; Savio, D.; Huang, M.; Weiss, C.; Tomer, Y.; McLane, M.P.; Nicolaides, N.C.; et al. Characterization of a calcium-activated chloride channel as a shared target of Th2 cytokine pathways and its potential involvement in asthma. Am. J. Respir. Cell Mol. Biol. 2001, 25, 486-491. [CrossRef]

19. Hauber, H.P.; Lavigne, F.; Hung, H.L.; Levitt, R.C.; Hamid, Q. Effect of Th2 type cytokines on hCLCA1 and mucus expression in cystic fibrosis airways. J. Cyst. Fibros. 2010, 9, 277-279. [CrossRef] [PubMed]

20. Gibson, A.; Lewis, A.P.; Affleck, K.; Aitken, A.J.; Meldrum, E.; Thompson, N. hCLCA1 and mCLCA3 are secreted non-integral membrane proteins and therefore are not ion channels. J. Biol. Chem. 2005, 280, 27205-27212. [CrossRef] [PubMed]

21. Sala-Rabanal, M.; Yurtsever, Z.; Nichols, C.G.; Brett, T.J. Secreted CLCA1 modulates TMEM16A to activate Ca(2+)-dependent chloride currents in human cells. eLife 2015, 4, e05875. [CrossRef] [PubMed]

22. Sala-Rabanal, M.; Yurtsever, Z.; Berry, K.N.; Nichols, C.G.; Brett, T.J. Modulation of TMEM16A channel activity by the von Willebrand factor type A (VWA) domain of the calcium-activated chloride channel regulator 1 (CLCA1). J. Biol. Chem. 2017, 292, 9164-9174. [CrossRef]

23. Patel, A.C.; Morton, J.D.; Kim, E.Y.; Alevy, Y.; Swanson, S.; Tucker, J.; Huang, G.; Agapov, E.; Phillips, T.E.; Fuentes, M.E.; et al. Genetic segregation of airway disease traits despite redundancy of calcium-activated chloride channel family members. Physiol. Genom. 2006, 25, 502-513. [CrossRef]

24. Mundhenk, L.; Johannesson, B.; Anagnostopoulou, P.; Braun, J.; Bothe, M.K.; Schultz, C.; Mall, M.A.; Gruber, A.D. mCLCA3 does not contribute to calcium-activated chloride conductance in murine airways. Am. J. Respir. Cell Mol. Biol. 2012, 47, 87-93. [CrossRef]

25. Nyström, E.E.L.; Birchenough, G.M.H.; van der Post, S.; Arike, L.; Gruber, A.D.; Hansson, G.C.; Johansson, M.E.V. Calciumactivated Chloride Channel Regulator 1 (CLCA1) Controls Mucus Expansion in Colon by Proteolytic Activity. EBioMedicine 2018, 33, 134-143. [CrossRef]

26. Xiao, Q.; Yu, K.; Perez-Cornejo, P.; Cui, Y.; Arreola, J.; Hartzell, H.C. Voltage- and calcium-dependent gating of TMEM16A/Ano1 chloride channels are physically coupled by the first intracellular loop. Proc. Natl. Acad. Sci. USA 2011, 108, 8891-8896. [CrossRef] [PubMed]

27. Cabrita, I.; Benedetto, R.; Fonseca, A.; Wanitchakool, P.; Sirianant, L.; Skryabin, B.V.; Schenk, L.K.; Pavenstadt, H.; Schreiber, R.; Kunzelmann, K. Differential effects of anoctamins on intracellular calcium signals. FASEB J. 2017, 31, 2123-2134. [CrossRef]

28. Rajavelu, P.; Chen, G.; Xu, Y.; Kitzmiller, J.A.; Korfhagen, T.R.; Whitsett, J.A. Airway epithelial SPDEF integrates goblet cell differentiation and pulmonary Th2 inflammation. J. Clin. Investig. 2015, 125, 2021-2031. [CrossRef]

29. Chen, G.; Korfhagen, T.R.; Xu, Y.; Kitzmiller, J.; Wert, S.E.; Maeda, Y.; Gregorieff, A.; Clevers, H.; Whitsett, J.A. SPDEF is required for mouse pulmonary goblet cell differentiation and regulates a network of genes associated with mucus production. J. Clin. Investig. 2009, 119, 2914-2924. [CrossRef] [PubMed]

30. Park, K.S.; Korfhagen, T.R.; Bruno, M.D.; Kitzmiller, J.A.; Wan, H.; Wert, S.E.; Khurana Hershey, G.K.; Chen, G.; Whitsett, J.A. SPDEF regulates goblet cell hyperplasia in the airway epithelium. J. Clin. Investig. 2007, 117, 978-988. [CrossRef] [PubMed]

31. Walters, M.S.; Gomi, K.; Ashbridge, B.; Moore, M.A.; Arbelaez, V.; Heldrich, J.; Ding, B.S.; Rafii, S.; Staudt, M.R.; Crystal, R.G. Generation of a human airway epithelium derived basal cell line with multipotent differentiation capacity. Respir. Res. 2013, 14, 135. [CrossRef] [PubMed]

32. Wisnewski, A.V.; Liu, J.; Redlich, C.A. Analysis of Lung Gene Expression Reveals a Role for Cl- channels in Diisocyanate Induced Airway Eosinophilia in a Mouse Model of Asthma Pathology. Am. J. Respir. Cell Mol. Biol. 2020, 63, 25-35. [CrossRef] [PubMed]

33. Scudieri, P.; Caci, E.; Bruno, S.; Ferrera, L.; Schiavon, M.; Sondo, E.; Tomati, V.; Gianotti, A.; Zegarra-Moran, O.; Pedemonte, N.; et al. Association of TMEM16A chloride channel overexpression with airway goblet cells metaplasia. J. Physiol. 2012, 590, 6141-6155. [CrossRef]

34. Qin, Y.; Jiang, Y.; Sheikh, A.S.; Shen, S.; Liu, J.; Jiang, D. Interleukin-13 stimulates MUC5AC expression via a STAT6-TMEM16AERK1/2 pathway in human airway epithelial cells. Int. Immunopharmacol. 2016, 40, 106-114. [CrossRef]

35. Kang, J.W.; Lee, Y.H.; Kang, M.J.; Lee, H.J.; Oh, R.; Min, H.J.; Namkung, W.; Choi, J.Y.; Lee, S.N.; Kim, C.H.; et al. Synergistic mucus secretion by histamine and IL-4 through TMEM16A in airway epithelium. Am. J. Physiol. Lung Cell Mol. Physiol. 2017, 313, L466-L476. [CrossRef]

36. Jin, X.; Shah, S.; Liu, Y.; Zhang, H.; Lees, M.; Fu, Z.; Lippiat, J.D.; Beech, D.J.; Sivaprasadarao, A.; Baldwin, S.A.; et al. Activation of the Cl- Channel ANO1 by Localized Calcium Signals in Nociceptive Sensory Neurons Requires Coupling with the IP3 Receptor. Sci. Signal. 2013, 6, ra73. [CrossRef] [PubMed]

37. Duvvuri, U.; Shiwarski, D.J.; Xiao, D.; Bertrand, C.; Huang, X.; Edinger, R.S.; Rock, J.R.; Harfe, B.D.; Henson, B.J.; Kunzelmann, K.; et al. TMEM16A, induces MAPK and contributes directly to tumorigenesis and cancer progression. Cancer Res. 2012, 72, 3270-3281. [CrossRef] [PubMed]

38. Cabrita, I.; Kraus, A.; Scholz, J.K.; Skoczynski, K.; Schreiber, R.; Kunzelmann, K.; Buchholz, B. Cyst growth in ADPKD is prevented by pharmacological and genetic inhibition of TMEM16A in vivo. Nat. Commun. 2020, 11, 4320. [CrossRef] 
39. Ruiz, C.; Martins, J.R.; Rudin, F.; Schneider, S.; Dietsche, T.; Fischer, C.A.; Tornillo, L.; Terracciano, L.M.; Schreiber, R.; Bubendorf, L.; et al. Enhanced Expression of ANO1 in Head and Neck Squamous Cell Carcinoma Causes Cell Migration and Correlates with Poor Prognosis. PLoS ONE 2012, 7, e43265. [CrossRef]

40. Ousingsawat, J.; Martins, J.R.; Schreiber, R.; Rock, J.R.; Harfe, B.D.; Kunzelmann, K. Loss of TMEM16A causes a defect in epithelial Ca2+ dependent chloride transport. J. Biol. Chem. 2009, 284, 28698-28703. [CrossRef] [PubMed]

41. Rock, J.R.; O'Neal, W.K.; Gabriel, S.E.; Randell, S.H.; Harfe, B.D.; Boucher, R.C.; Grubb, B.R. Transmembrane protein 16A (TMEM16A) is a Ca2+ regulated Cl-Secretory channel in mouse airways. J. Biol. Chem. 2009, 284, 14875-14880. [CrossRef] [PubMed]

42. Vega, G.; Guequén, A.; Philp, A.R.; Gianotti, A.; Arzola, L.; Villalón, M.; Zegarra-Moran, O.; Galietta, L.J.; Mall, M.A.; Flores, C.A. Lack of Kcnn4 improves mucociliary clearance in muco-obstructive lung disease. JCI Insight 2020, 5, e140076. [CrossRef]

43. Mall, M.; Gonska, T.; Thomas, J.; Schreiber, R.; Seydewitz, H.H.; Kuehr, J.; Brandis, M.; Kunzelmann, K. Modulation of Ca2+ activated Cl- secretion by basolateral $\mathrm{K}+$ channels in human normal and cystic fibrosis airway epithelia. Pediatric Res. 2003, 53, 608-618. [CrossRef]

44. Bernard, K.; Bogliolo, S.; Soriani, O.; Ehrenfeld, J. Modulation of calcium-dependent chloride secretion by basolateral SK4-like channels in a human bronchial cell line. J. Membr. Biol. 2003, 196, 15-31. [CrossRef]

45. Lee, R.J.; Foskett, J.K. Ca signaling and fluid secretion by secretory cells of the airway epithelium. Cell Calcium 2014, 55, 325-336. [CrossRef]

46. Lee, R.J.; Foskett, J.K. cAMP-activated Ca2+ signaling is required for CFTR-mediated serous cell fluid secretion in porcine and human airways. J. Clin. Investig. 2010, 120, 3137-3148. [CrossRef] [PubMed]

47. Devor, D.C.; Singh, A.K.; Lambert, L.C.; DeLuca, A.; Frizzell, R.A.; Bridges, R.J. Bicarbonate and chloride secretion in Calu-3 human airway epithelial cells. J. Gen. Physiol. 1999, 113, 743-760. [CrossRef] [PubMed]

48. Lee, R.J.; Harlow, J.M.; Limberis, M.P.; Wilson, J.M.; Foskett, J.K. HCO3(-) secretion by murine nasal submucosal gland serous acinar cells during Ca2+-stimulated fluid secretion. J. Gen. Physiol. 2008, 132, 161-183. [CrossRef]

49. Lee, R.J.; Foskett, J.K. Mechanisms of Ca2+-stimulated fluid secretion by porcine bronchial submucosal gland serous acinar cells. Am. J. Physiol. Lung Cell Mol. Physiol. 2009, 298, L210-L231. [CrossRef] [PubMed]

50. Truong, E.C.; Phuan, P.W.; Reggi, A.L.; Ferrera, L.; Galietta, L.J.V.; Levy, S.E.; Moises, A.C.; Cil, O.; Diez-Cecilia, E.; Lee, S.; et al. Substituted 2-Acylaminocycloalkylthiophene-3-carboxylic Acid Arylamides as Inhibitors of the Calcium-Activated Chloride Channel Transmembrane Protein 16A (TMEM16A). J. Med. Chem. 2017, 60, 4626-4635. [CrossRef]

51. Cabrita, I.; Benedetto, R.; Schreiber, R.; Kunzelmann, K. Niclosamide repurposed for the treatment of inflammatory airway disease. JCI Insight 2019, 8, e128414. [CrossRef] [PubMed]

52. Nyström, E.E.L.; Arike, L.; Ehrencrona, E.; Hansson, G.C.; Johansson, M.E.V. Calcium-activated chloride channel regulator 1 (CLCA1) forms non-covalent oligomers in colonic mucus and has mucin 2-processing properties. J. Biol. Chem. 2019, 294, 17075-17089. [CrossRef] [PubMed]

53. Hamann, M.; Gibson, A.; Davies, N.; Jowett, A.; Walhin, J.P.; Partington, L.; Affleck, K.; Trezise, D.; Main, M. Human ClCa1 modulates anionic conduction of calcium-dependent chloride currents. J. Physiol. 2009, 587, 2255-2274. [CrossRef] [PubMed]

54. Tian, Y.; Schreiber, R.; Wanitchakool, P.; Kongsuphol, P.; Sousa, M.; Uliyakina, I.; Palma, M.; Faria, D.; Traynor-Kaplen, A.E.; Fragata, J.I.; et al. Control of TMEM16A by INO-4995 and other inositolphosphates. Br. J. Pharm. 2013, 168, 253-265. [CrossRef] [PubMed]

55. Centeio, R.; Cabrita, I.; Benedetto, R.; Talbi, K.; Ousingsawat, J.; Schreiber, R.; Sullivan, J.K.; Kunzelmann, K. Pharmacological Inhibition and Activation of the $\mathrm{Ca}(2+)$ Activated Cl(-) Channel TMEM16A. Int. J. Mol. Sci. 2020, 21, 2557. [CrossRef] [PubMed]

56. Schreiber, R.; Castrop, H.; Kunzelmann, K. Allergen induced airway hyperresponsiveness is absent in ecto-5'-nucleotidase (CD73) deficient mice. Pflug. Arch. 2008, 457, 431-440. [CrossRef]

57. Schreiber, R.; Uliyakina, I.; Kongsuphol, P.; Warth, R.; Mirza, M.; Martins, J.R.; Kunzelmann, K. Expression and Function of Epithelial Anoctamins. J. Biol. Chem. 2010, 285, 7838-7845. [CrossRef] [PubMed] 